\title{
MUTATION FREQUENCIES OF MOTILE AEROMONAS SPP. FROM CULTURED CARPS AGAINST OXYTETRACYCLINE AND CHLORAMPHENICOL
}

\author{
A. BARDHAN, Q. AIN QURESHI AND T. J. ABRAHAM* \\ Department of Aquatic Animal Health, Faculty of Fishery Sciences \\ West Bengal University of Animal and Fishery Sciences \\ Chakgaria, Kolkata - 700 094, West Bengal, India
}

\begin{abstract}
Aeromonas spp. are autochthonous in the aquatic environment and known for their aetiological role in motile Aeromonas septicaemia (MAS) of freshwater fish. In the present study, the susceptibility of five motile Aeromonas strains from the aquaculture environment was tested against 12 antibiotics. The mutation frequencies and minimal inhibitory concentrations (MICs) of oxytetracycline, an approved antibiotic and chloramphenicol, a banned antibiotic for aquaculture use were determined against $A$. hydrophila $(\mathrm{n}=3)$, A. caviae $(\mathrm{n}=1)$ and A. tecta $(\mathrm{n}=1)$. The MICs of oxytetracycline and chloramphenicol were in the range of $0.39-6.25 \mu \mathrm{g} / \mathrm{mL}$ and $3.125-6.25 \mu \mathrm{g} / \mathrm{mL}$, respectively. The mutation frequencies to oxytetracycline and chloramphenicol at $25 \mu \mathrm{g} / \mathrm{mL}$ were in the range of $5.94 \times 10^{-7}-8.25 \times 10^{-7}$ and $1.20 \times 10^{-7}-8.33 \times 10^{-7}$, respectively. The multiple antibiotic-resistance (MAR) index among the motile Aeromonas strains of the aquaculture environment varied between $0.44 \%$ and $0.56 \%$, which is of great concern.
\end{abstract}

Key words: Chloramphenicol, Motile Aeromonas spp., Multiple antibiotic resistance, Mutation frequency, Oxytetracycline

West Bengal is one of the highest producers of freshwater table fish and fish seeds in the country (Department of Fisheries, 2019). Aquaculture production of West Bengal has seen an increasing trend with a production of 17.42 lakh tonnes in the year 2017-18, second among the fish producing states of India (Department of Fisheries, 2019). Among the 20 districts of West Bengal, North and South 24 Parganas are the two most aquaculturally important districts, contributing to nearly $70 \%$ of the total aquaculture production of the state (Department of Fisheries, 2019). The Indian major carps (IMCs), viz., Labeo rohita, Catla catla and Cirrhinus mrigala are the mainstay of freshwater aquaculture, which contribute $87 \%$ of the total freshwater aquaculture production of the country (Mohanty et al., 2017). Bacterial diseases are one of the main problems of freshwater aquaculture with motile Aeromonas septicaemia (MAS) causing huge mortalities in IMCs (Stratev and Odeyemi, 2017).

${ }^{*}$ Corresponding Author 
Aeromonas spp. are Gram-negative and facultative anaerobic bacteria, which are ubiquitous in the aquatic environments (Graf, 2015) and pathogenic to fish as well as humans (Stratev and Odeyemi, 2016). Motile aeromonads, as primary and opportunistic pathogens, have demanded a lot of attention with the use of various antimicrobials in aquaculture (Stratev and Odeyemi, 2017). The use of oxytetracycline (OTC) has been proved to be efficient against MAS (Stratev and Odeyemi, 2017). However, with their extensive use, antimicrobial resistance (AMR) has become a harsh consequence (Romero et al., 2012). Motile Aeromonas strains from cultured freshwater fish like C. catla, L. rohita and Ctenopharyngodon idella had been seen to acquire a relatively high resistance to OTC, amoxycillin, ampicillin, novobiocin and polymixin-B, possibly attributed to the use of antibiotics in aquaculture (Hatha et al., 2005). Most mesophilic motile aeromonads are resistant to ampicillin, cephalothin and trimethoprim and susceptible to ciprofloxacin and ceftriaxone (Bhowmick $e t$ $a l ., 2018)$. In recent years, the prevalence of multiple antibiotic resistance (MAR) among the motile aeromonads has been the major cause for concern (Romero et al., 2012; Graf, 2015). Since West Bengal is one of the major fish producing states of India with high per capita consumption and demand for freshwater fish, the present study attempted to assess the antibiotic sensitivity of motile aeromonads of aquaculture environment, and determine the minimal inhibitory concentration (MIC) and frequencies of mutation against OTC and chloramphenicol.

\section{MATERIALS AND METHODS}

Bacterial strains: The chloramphenicol and OTC sensitive $\left(\mathrm{C}^{\mathrm{s}}, \mathrm{O}^{\mathrm{S}}\right)$ motile aeromonad strains, viz., A. hydrophila $(\mathrm{n}=3)$, A. caviae $(\mathrm{n}=1)$ and A. tecta $(\mathrm{n}=1)$ of this study were from the collections of the Department of Aquatic Animal Health, Faculty of Fishery Sciences, Kolkata. The details of these strains, the location and source of the collection are presented in Table 1.

Antibiotic sensitivity: The sensitivity of motile Aeromonas spp. to 12 antibiotics (HiMedia, India), viz., amoxyclav (30 $\mu \mathrm{g})$, azithromycin $(15 \mu \mathrm{g})$, cefalexin $(30 \mu \mathrm{g})$, chloramphenicol $(30 \mu \mathrm{g})$, ciprofloxacin $(5 \mu \mathrm{g})$, co-trimoxazole $(25 \mu \mathrm{g})$, enrofloxacin $(10 \mu \mathrm{g})$, gentamycin $(10 \mu \mathrm{g})$, nitrofurantoin (300 $\mu \mathrm{g})$, oxytetracycline $(30 \mu \mathrm{g})$, sulfafurazole $(300 \mu \mathrm{g})$ and trimethoprim $(10 \mu \mathrm{g})$ was tested by agar-disc diffusion technique (CLSI, 2012) on Mueller Hinton agar (MHA) at $35 \pm 2{ }^{\circ} \mathrm{C}$. Interpretation of sensitivity was based on the zone size interpretation chart (CLSI, 2012). Multiple antibiotic resistance (MAR) index of a particular strain was computed as " $\mathrm{a} / \mathrm{b}$ ", where "a" signified the number of antibiotic groups the strain was resistant to and "b" signified the total number of antibiotic groups against which the antibiotic sensitivity assay was carried out for that particular strain (Magiorakos et al., 2012).

Minimal inhibitory concentration of oxytetracycline and chloramphenicol: Five $\mathrm{C}^{\mathrm{S}}, \mathrm{O}^{\mathrm{S}}$ strains comprising $A$. hydrophila, A. caviae and A. tecta were used for determining the MICs of OTC, an approved antibiotic and chloramphenicol, a banned 
antibiotic for aquaculture use by agar dilution method (CLSI, 2012). Oxytetracycline dihydrate and chloramphenicol (HiMedia, India) stock solutions $(1000 \mu \mathrm{g} / \mathrm{mL})$ prepared as per CLSI (2011) were used for the preparation of MHA plates with appropriate antibiotics and concentrations ranging from 0 to $100 \mu \mathrm{g} / \mathrm{mL}$. The MHA plates with OTC and/or chloramphenicol at various concentrations were spot inoculated with 2 $\mu \mathrm{L}\left(\sim 10^{5}\right.$ cells $)$ of young bacterial culture, incubated for 48 hours at $35 \pm 2^{\circ} \mathrm{C}$ and observed for growth. The lowest concentration of the antibiotic that inhibited the visible bacterial growth was considered as the MIC.

Mutation frequency: The mutation frequencies of Aeromonas spp. were determined as per Gustafsson et al. (2003) with minor modifications. The MHA plates with desired concentrations of chloramphenicol or OTC at $25 \mu \mathrm{g} / \mathrm{mL}$ each were prepared separately. Freshly prepared bacterial cell suspensions $\left(\sim 10^{10}\right.$ cells $)$ were serially diluted up to $10^{-8}$ level in sterile saline. Aliquots $(0.1 \mathrm{~mL})$ of cell suspension from undiluted, $10^{-1}, 10^{-2}, 10^{-3}, 10^{-4}$ and $10^{-}$ 5 dilutions were then spread plated on to MHA plates containing chloramphenicol or OTC. Simultaneously, $0.1 \mathrm{~mL}$ each of $10^{-7}$ and $10^{-8}$ dilutions of the cell suspension was spread plated on to antibiotic-free MHA plates and incubated at $35 \pm 2{ }^{\circ} \mathrm{C}$ for 5-7 days. The number of growing colonies on the plates was counted and mutation frequencies calculated as given below.

Mutation frequency of motile Aeromonas $=\mathrm{Na} / \mathrm{N}$, where,

$\mathrm{Na}=$ Number of colonies on MHA plates containing chloramphenicol or OTC
$\mathrm{N}=$ Number of colonies on MHA plates without antibiotic

\section{RESULTS}

Antibiotic sensitivity: The antibiotic sensitivity of motile Aeromonas spp. are presented in Table 1. Aeromonas hydrophila strains (6BM, FBM9 and CR8) were sensitive to chloramphenicol, ciprofloxacin, co-trimoxazole, enrofloxacin, oxytetracycline, sulfafurazole and trimethoprim. Aeromonas caviae $\mathrm{GHC}$ and A. tecta 9NR exhibited a similar resistance pattern as that of $A$. hydrophila $6 \mathrm{BM}$ and CR8. Resistance to gentamycin varied among the A. hydrophila strains. All the strains were resistant to amoxyclav, azithromycin, cefalexin and nitrofurantoin. The MAR indices for A. hydrophila, $A$. caviae and $A$. tecta strains were in the range of $0.44-0.56$.

Minimal inhibitory concentrations of oxytetracycline and chloramphenicol: The MICs of OTC ranged between $0.39 \mu \mathrm{g} / \mathrm{mL}$ and $3.125 \mu \mathrm{g} / \mathrm{mL}$ for A. hydrophila strains, $6.25 \mu \mathrm{g} / \mathrm{mL}$ for A. caviae and $1.56 \mu \mathrm{g} / \mathrm{mL}$ for A. tecta. The MICs of chloramphenicol varied between $3.125 \mu \mathrm{g} / \mathrm{mL}$ and $6.25 \mu \mathrm{g} /$ $\mathrm{mL}$ for A. hydrophila, A. caviae and A. tecta strains (Table 1).

Mutation frequencies of motile Aeromonas spp.: The mutation frequencies of motile aeromonads to OTC $(25 \mu \mathrm{g} / \mathrm{mL})$ were in the range of $5.94 \times 10^{-7}$ (A. tecta $9 \mathrm{NR}$ )- $8.25 \times 10^{-7}$ (A.hydrophilaCR8).The mutation frequencies of motile aeromonads to chloramphenicol $(25 \mu \mathrm{g} / \mathrm{mL})$ ranged from $1.20 \times 10^{-7}$ in A. tecta 9NR to $8.33 \times 10^{-7}$ in $A$. hydrophila CR 8 (Table 1). 


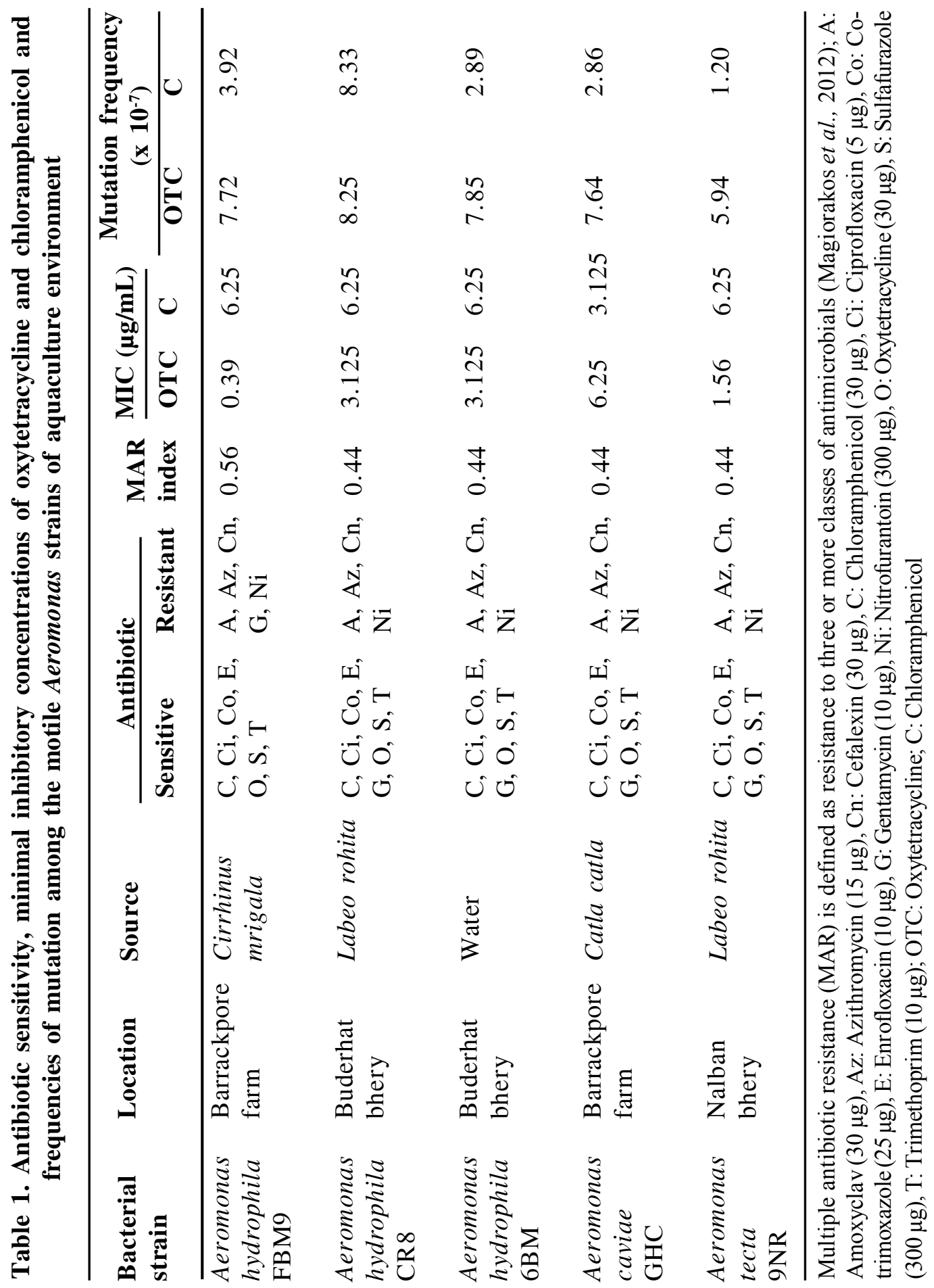




\section{DISCUSSION}

In the present study, all the $\mathrm{C}^{\mathrm{S}}$ and $\mathrm{O}^{\mathrm{S}}$ motile aeromonads from the aquaculture environment exhibited a similar antibioticresistance pattern, except for gentamicin. All the strains were resistant to amoxyclav, azithromycin, cefalexin and nitrofurantoin The MAR index observed among the motile aeromonads of aquacultured farms and their environment varied between 0.44 and 0.56 , which is of great concern because a sample with MAR index above 0.2 is considered to be exceedingly manifested with antibiotics and having a high-risk factor (Saka et al., 2017). It is worth mentioning here that the sampling locations, viz., Buderhat bhery and Barrackpore farm were close to highly populated cities and had hospitals and dumping grounds in their vicinity. Further, the Nalban bhery used biologically treated sewage, which is considered to be highly contaminated with antibiotic-resistant bacteria [ARB] (Abraham, 2011).

The MICs of OTC were within the range of $0.39-6.25 \mu \mathrm{g} / \mathrm{mL}$ for A. hydrophila and A. tecta and $A$. caviae strains, which was within the set levels for the susceptible strains (CLSI, 2012). In contrast, Lukkana et al. (2011) documented wide variations in the MICs of OTC against A. hydrophila in the range of 0.06-64 $\mu \mathrm{g} / \mathrm{mL}$. Baron et al. (2017) in their study also showed that MICs of OTC for Aeromonas spp. were in the range of $0.062-128 \mu \mathrm{g} / \mathrm{mL}$. The MICs of chloramphenicol were in the narrow range of $3.125-6.25 \mu \mathrm{g} / \mathrm{mL}$ for motile Aeromonas spp. On the other hand, the results of Majeed (2011) documented MICs above $100 \mu \mathrm{g} / \mathrm{mL}$ $(128 \mu \mathrm{g} / \mathrm{mL})$ for chloramphenicol against $A$. hydrophila. The MIC results of the present study confirmed the susceptibility of motile Aeromonas spp. from West Bengal aquaculture environments towards chloramphenicol and OTC.

Mutation frequencies of motile aeromonads of the present study against OTC $\left(5.94 \times 10^{-}\right.$ 7. $8.25 \times 10^{-7}$ ) were comparable with the results of Bharathkumar and Abraham (2013). They demonstrated mutation frequencies in the range of $6.71 \times 10^{-9}$ and $1.60 \times 10^{-6}$ against OTC for A. hydrophila strains. The frequencies of mutation in motile aeromonads strains against chloramphenicol followed a similar trend and ranged between $1.20 \times 10^{-7}$ and $8.33 \times 10^{-}$ 7. In nature, bacterial DNA mutations occur at 1 in $10^{8}$ cells (Watford and Warrington, 2017). The results of the present study showed that the $\mathrm{C}^{\mathrm{s}}$ and $\mathrm{O}^{\mathrm{s}}$ motile aeromonads from the aquaculture environment are mutating at about $1-8$ in $10^{7}$ cells, which is comparatively higher than in the natural population (Watford and Warrington, 2017). As opined by Denamur and Matic (2006), the increased mutation rates in motile aeromonads of aquaculture environment may lead to considerably high proportions of the bacterial population with AMR. Theoretical considerations and experimental studies (Giraud et al., 2002) showed that the levels of mutators may be enriched when bacteria are exposed to a changing environment especially while repeated challenges of antibiotics are performed. Also, a positive correlation between MAR and high mutation rates is expected to be frequent in natural populations of bacterial pathogens (Knopp and Andersson, 2018). The bacterial resistance to chloramphenicol and OTC results from genes that are located on 
horizontally transferred genetic elements (e.g. plasmids) and a mutator is not expected to increase the rate of plasmid transfer (Gustafsson et al., 2003). The ability to follow the antibacterial susceptibility trend and AMR over a long period of time is crucial to monitor antibiotic-resistance dissemination in the environment like aquaculture systems. In this regard, Aeromonas would be a perfect model organism to report on antibiotic-resistance in the freshwater aquaculture environment.

In general, the results of the present study indicated the prevalence of AMR among the motile aeromonads of freshwater aquaculture systems of West Bengal. This study also documented considerably higher

\section{REFERENCES}

Abraham TJ, 2011. Food safety hazards related to emerging antibiotic resistant bacteria in cultured freshwater fish of Kolkata, India. Adv J Food Sci Technol, 3(1): 69-72

Baron S, Granier SA, Larvor E, Jouy E, Cineux M et al., 2017. Aeromonas diversity and antimicrobial susceptibility in freshwater an attempt to set generic epidemiological cut-off values. Front Microbiol, 8: 503

Bharathkumar G and Abraham TJ, 2013. Prevalence of transferable oxytetracycline resistance factors in Aeromonas hydrophila in fish hatcheries. Fish Technol, 50: 324-330

Bhowmick UD and Bhattacharjee S, 2018. Bacteriological, clinical and virulence aspects of Aeromonas-associated diseases in humans. Pol J Microbiol, 67: 137-149

CLSI, 2011. Methods for Antimicrobial Susceptibility Testing for Human frequencies of mutation among the motile aeromonads. As the usage of antimicrobials is not regulated in India, repeated challenges of antibiotics in freshwater aquaculture may expose the motile aeromonads and other aquatic bacteria to a changing environment, which could be the root source and origin of higher levels of ARB.

\section{ACKNOWLEDGEMENT}

The research work was supported by the Indian Council of Agricultural Research, Government of India, New Delhi under the All India Network Project on Fish Health. The authors thank the Vice-Chancellor, West Bengal University of Animal and Fishery Sciences, Kolkata for providing necessary infrastructure facility to carry out the work.

Mycoplasmas; Approved Guidelines M43A. Clinical and Laboratory Standards Institute, 950 West Valley Road, Suite 2500, Wayne, Pennsylvania 19087, USA

CLSI, 2012. Performance Standards for Antimicrobial Disk Susceptibility Tests, Approved Standard, M02-A11. Clinical and Laboratory Standards Institute, 950 West Valley Road, Suite 2500, Wayne, Pennsylvania 19087, USA

Denamur E and Matic I, 2006. Evolution of mutation rates in bacteria. Mol Microbiol, 60(4): 820-827

Department of Fisheries, 2019. Handbook on Fisheries Statistics 2018. Ministry of Fisheries, Animal Husbandry and Dairying, Govt. of India, New Delhi

Giraud A, Matic I, Radman M, Fons M and Taddei F, 2002. Mutator bacteria as a risk factor in 
treatment of infectious diseases. Antimicrob Agents and Chemother, 46(3): 863-865

Graf J, 2015. Aeromonas. Caister Academic Press, Norfolk, UK

Gustafsson I, Sjölund M, Torell E, Johannesson M, Engstrand L et al., 2003. Bacteria with increased mutation frequency and antibiotic resistance are enriched in the commensal flora of patients with high antibiotic usage. $\mathrm{J}$ Antimicrob Chemother, 52(4): 645-650

Hatha M, Vivekanandhan AA and Joice GJ, 2005. Antibiotic resistance pattern of motile aeromonads from farm-raised freshwater fish. Int J Food Microbiol, 98(2): 131-134

Knopp M and Andersson DI, 2018. Predictable phenotypes of antibiotic resistance mutations. MBio, 9(3): e00770-18

Lukkana M, Wongtavatchai J and Chuanchuen R, 2011. Class 1 integrons in Aeromonas hydrophila isolates from farmed Nile tilapia (Oreochromis niloticus). J Vet Med Sci, 74(4): 435-40

Magiorakos AP, Srinivasan A, Carey RB, Carmeli Y, Falagas ME et al., 2012. Multidrugresistant, extensively drug-resistant and pandrug-resistant bacteria: an international expert proposal for interim standard definitions for acquired resistance. Clin Microbiol Infect, 18(3): 268-281

Majeed HAA, 2011. Characterization of Aeromonas hydrophila isolated from patients with diarrhea. J Kerbala Uni, 9(3): 33-42
Mohanty RK, Ambast SK, Panda DK, Thakur AK and Mohanty S, 2017. Density-dependent water use in carp polyculture: Impacts on production performance and water productivity. Aquaculture 470: 32-39

Romero J, Feijoó CG and Navarrete P, 2012. Antibiotics in aquaculture-use, abuse and alternatives. Health and Environment in Aquaculture. Carvalho ED, David GS and Reinaldo J (Eds.), ISBN: 978-953-51-04971, InTech, pp: 159-198. Available from: http://www.intechopen.com/books/healthand-environment-in-aquaculture/ antibiotics in-aquaculture-use-abuse-andalternatives-

Saka BA, Adeyemo OK and Odeseye AO, 2017. Multiple antibiotic resistance indices of Aeromonas hydrophila isolates of muscle of catfish (Clarias gariepinus, Burchell 1822) from selected markets in Ibadan, Nigeria. Afr J Clin Exp Microbiol, 18(2): 73-78

Stratev D and Odeyemi OA, 2016. Antimicrobial resistance of Aeromonas hydrophila isolated from different food sources: A mini-review. J Infect Public Heal, 9(5): 535-544

Stratev D and Odeyemi OA, 2017. An overview of motile Aeromonas septicaemia management. Aquacult Int, 25(3): 10951105

Watford S and Warrington SJ, 2017. Bacterial DNA mutations. In StatPearls [Internet]. Treasure Island (FL): StatPearls Publishing LLC. Available from: https:// www.ncbi.nlm.nih.gov/books/NBK459274/ 